\title{
Understanding the Politics of Latin America's Plural Lefts (Chávez/Lula): social democracy, populism and convergence on the path to a post-neoliberal world
}

\section{JOHN D FRENCH}

ABSTRACT This article explores the academic and public debate on the politics of Latin America's twenty-first century turn towards the left. It rejects dichotomous categorisations of 'social democratic' and 'populist' lefts as a disciplinary move by neoliberals that appeals to entrenched liberal predispositions. It suggests that such classificatory taxonomies are directly linked to an impoverished notion of the political, in which a politics of exalted expertise and enlightenment, based on reason, rationality and objectivity is juxtaposed against a lesser sphere of emotion, passion and 'personalism'. This underlying dualism, which permeates academic disciplines and crosses lines of ideology, tracks established markers of hierarchical distinction in societies profoundly divided along multiple lines of class and cultural capital. This is explored through an analysis of the discourse of Chávez vis-a-vis Lula, while offering an appreciation of the subaltern origin of Lula's distinctive style of political leadership, from trade unionism to the presidency, based upon the creation of spaces of convergence.

This article takes up the heated political and academic debate regarding the twenty-first century turn towards the left in Latin America. It opens with a January 2006 speech by Hugo Chávez that rejects the dichotomous categorisation of the contemporary Latin American left championed by former Mexican foreign minister Jorge Castañeda, former Mexican president Ernesto Zedillo, and many political scientists. This juxtaposition of the 'social democratic' against the 'populist' in Latin America originated as a disciplinary move by neoliberals but its appeal went beyond that limited group. Reflecting entrenched predispositions and long-established liberal values, sectors of a discouraged Latin American intelligentsia responded to the global transformations of 1989-91 by embracing a variant of 
neoliberalism under the label of 'social democracy', a term they now propose to apply to an anti-neoliberal left that has risen to national elective office.

After clarifying its political genealogy, the article links this classificatory taxonomy to an impoverished and antiquated notion of the political. In postulating a politics of exalted expertise and enlightenment, the idea of reason, rationality and objectivity (the 'cold' and disinterested) is juxtaposed against a lesser sphere of emotion, passion and 'personalism' (the 'hot' and blindly partisan, if not backward and corrupt). Beyond historicising the relation between intellectuals, liberalism and populism, this article argues that the essence of the art of politics does not lie in the conceptual schemes, analytical categories and abstract grids derived from social theory and economics; it is to be found in the lived relations between humans, understood as flesh-and-blood individuals, friends and foes, and groups-information (or decay). As work done with words, politics is necessarily discursive and gains strength from its dynamic insertion into the cultural and symbolic universe that characterises a Latin America profoundly divided along multiple lines of race, class and cultural capital.

Embracing the notion of many lefts but one path, the article uses Hugo Chávez's discussion of Lula to better understand the lived politics of Latin America's plural lefts. The key to the unity that exists within the left's diversity, it is suggested, can be found in the notion of the left as space of convergence across difference. In 1991 this took form as the Forum of São Paulo, which brought together the region's leftist organizations, and a decade later as the World Social Forum founded in Porto Alegre, Brazil in 2001. Finally, it argues that leadership - understood as a unity, as in the case of Chávez - can be distinguished from Lula's praxis of convergence but that this divergence need not endanger the shared left terrain that has provided the basis for the unprecedented success of this generation of Latin American leftists.

\section{The 'hot' and the 'cold': Chávez versus Castañeda on 'crazy' or 'social democratic' lefts}

'I never know where to begin [when] speaking in events as beautiful as this', Hugo Chávez told an overflowing crowd in the Caracas Poliedro on 27 January 2006. The Venezuelan president began his address to the polycentric VI World Social Forum (WSF) by citing 'the grand emotion' he felt facing an audience 'overflowing with passion'. In a speech full of references to past heroes, Chávez delivered a message to 'Mr Danger', the term he selected for a US president he would label the devil in his speech to the UN General Assembly in September 2006. On occasions like this rally, he observed, 'I always come with the desire, the intention and commitment to reflect on issues and ideas. And there lies the perpetual dilemma-passion vs reasonbut both are necessary.' While citing martyrs, condemning crimes and promising inevitable retribution, Chávez condemned those who failed to understand that the Latin American lefts that had come to power were all moving 'along the same path, in the same direction'. It is here that the Empire has shown itself to be very intelligent, he went on: intellectuals of 
diverse origin and the media have spent two years promoting the divisive idea that... several lefts exist: Fidel and Chávez are the crazies - and now they include Evo [Morales] too; and others, like Lula, Lagos, Tabaré and Kirchner are "statesmen"; but Chávez and Fidel are crazy, the "crazy left".' Having weighed in on the key debate about Latin America's left turns, Chávez went on with vigour to discount such labels: 'call us what they will, but we are going to give the right the greatest defeat ever on this continent, which will be remembered for 500000 years'.

As if following up on Chávez's remarks, the May-June 2006 issue of the US journal Foreign Affairs published an article by a Mexican intellectual Jorge Castañeda. The writer was well known among academics in the USA as author of an influential 1993 book on the twentieth century trajectory of the Latin American left and its subsequent crisis in the late 1980s. ${ }^{2}$ Yet the appearance of 'Latin America's left turn' in the journal of the US foreign policy establishment was not surprising. In the 1990s Castañeda had broken with his Mexican comrades to support the candidacy of a conservative businessman, Vicente Fox, who won a landmark 2000 presidential election that ended one-party rule in Mexico. Rewarded with the position of foreign minister, Castañeda's Foreign Affairs article has been widely cited and debated in both the academy and along the Washington-New York corridor.

Castañeda's article opened with a backward glance that took on the air of a fairy tale: 'just over a decade ago', Latin America seemed poised to begin 'a virtuous cycle of economic progress and improved democratic governance... The landscape today is transformed' with the region 'swerving left' in a backlash 'against the predominant trends of the last 15 years'. Dating this shift back to the 1998 election of Chávez in Venezuela, Castañeda described 'a veritable left wing tsunami', in which 'a wave of leaders, parties, and movements generically labeled "leftist" have swept to power'. Yet he was quick to sharply distinguish a 'good left', which was 'modern, open-minded, reformist and internationalist', from a Chávez left, 'born of the great tradition of Latin American populism', that was 'nationalist, strident, and close-minded'. ${ }^{3}$ While his 2006 article was far less balanced than his 1993 book, the article did attack populism as 'a bizarre blend of inclusion of the excluded, macroeconomic folly', and 'virulent strident nationalism'.

The vigour of Castañeda's disdain reflected how badly things had worked out for the neoliberal 'social democratic left' he had believed was the wave of the future in the early 1990s. Indeed, Castañeda was forced to admit in 2006 that he had been 'at least partially wrong' to have believed that the Latin American governments carrying out free market reforms in the 1990s would have to adopt 'social democratic' policies as the necessary complement to the modernising reforms vigorously denounced as neoliberal by the 'old, radical, guerrilla-based, Castroist, or communist left' (a category to which he had long consigned Lula and the Partido dos Trabalhadores-PT). ${ }^{5}$ In the 1990s the most successful examples of Castañeda-style 'social democracy' were the post-Pinochet Concertación in Chile, a coalition built around a SocialistChristian Democratic alliance, and the government of Fernando Henrique Cardoso, the neo-Marxist creator of dependency theory who served as 
Brazil's president from 1994 to 2002. Yet a decade later, Castañeda noted ruefully, only Chile had succeeded and few Latin Americans recognised Chile as the 'true model for the region'. ${ }^{6}$ As for Brazil, the 2002 election had seen a poorly educated former manual worker from the 'bad' left beat José Serra, an extremely competent administrator with a US PhD, who had been chosen by Cardoso's Brazilian Social Democratic Party (PSDB).

The sequence of sweeping electoral victories that marked the left's arrival in the first decade of the twenty-first century sprang from precisely the hardcore left of the past that had condemned the Castañeda-Cardoso brand of politics as neoliberal betrayal. ${ }^{7}$ In positioning himself vis-à-vis the new governing leftist leaders, the former Mexican foreign minister was reduced to miraculously rechristening swathes of the old 'bad' left he had opposed as newly 'social democratic', and thus part of what he now called the 'right left' in Latin America. Castañeda was full of praise for Tabaré Vazquez and the Frente Amplio in Uruguay, for example, but he was most eager to claim Brazilian President Lula for a renovated left that existed largely in his head. Yet his 'support' for Lula was tinged with resentment and his attempt to coopt Lula for the 'right left' was marked by clear uncertainty. Despite evidence of Lula's moderation, he claimed only that the PT had 'largely followed him [Lula] on the road toward social democracy,, 8 while admitting that it still maintained a 'lingering emotional devotion to Cuba', as did Lula. ${ }^{9}$ To illustrate the mixed nature of the Brazilian developments, he cited the fact that 'when Lula welcomed Bush' to Brasília in November 2005, there were demonstrators from Lula's own party burning 'the US president in effigy' across the street from the presidential palace. As he summed it up, 'the conversion is not complete'. ${ }^{10}$

So far I have traced the roots of dichotomous treatments of the Latin American left in the contemporary political dialogue between two Latin American politicians, each with their eye on Washington DC (if for different reasons). Yet this type of simplified hierarchised difference does not necessarily disappear when we move from the heated sphere of political antagonism into the more ethereal arena of academic social science. As political scientist Kenneth Roberts has recently observed, 'political diversity within Latin America's "left turn" is sometimes reduced to a core differentiation between social democratic and populist alternatives. This dichotomy is too quick to attach familiar labels to new phenomena in different contexts', not to mention, one might add, the multiplicity of meanings that the term 'social democratic' occupies historically within the western European context, much less its transformations over the past two decades. ${ }^{11}$ The second difficulty with this dichotomy, Roberts goes on, is that it 'lumps together too many disparate cases under the populist concept', which is transformed into a 'residual category' and 'political epithet' used to "demarcate the "good" or "responsible" left from the demagogues and "idiots" (in Vargas Llosa's contemptuous parlance)'. In doing so, an effort is made to 'delegitimize socio-economic alternatives that depart from neoliberal orthodoxy' while 'artificially reducing Latin America's options to one or another variant of populism or neoliberalism'. ${ }^{12}$ 
The political ploy described by Roberts was dramatically illustrated by a commentary on Lula's election by Ernesto Zedillo, a Yale economics PhD who served as the last PRI president before Vicente Fox. Appearing in the US business magazine Forbes, the article began by calling populism 'the most pervasive political ideology [sic] in Latin American politics for nearly a century [sic]'. He also noted, and by no means approvingly, that populism had proven 'extremely effective at attracting mass support' by using 'a socially divisive rhetoric' that promised 'a better life for their people simply by wishing for it - never as a result of discipline, thrift, and hard work'. Having sternly invoked a particularly disciplinary version of Weber's protestant ethic, the Director of Yale's Center for the Study of Globalisation described Lula as having run for president on three previous occasions 'on a populist platform'. As a result, investors had overreacted to the news of Lula's impending victory by driving down the value of the Brazilian real, although this might be 'a spillover effect from Argentina's irresponsible default on its foreign debt' in December 2001. ${ }^{13}$

Yet Zedillo reported himself hopeful that Lula might prove less than 'a traditional die-hard populist'. It may be, he went on, that in addition 'to being a charismatic politician, [Lula] may have evolved into a responsible one'. If so, the new president would rightly 'disappoint his now-enthusiastic grass-roots supporters' by doing the right thing: dosing 'his country with even more bitter medicine than that prescribed by the International Monetary Fund' in August 2002. If he refused, however, the result would be 'quite simply hell' for the economy and people of Brazil, and this would leave populism discredited. And if President Lula were perforce to act 'responsibly', he might — with generous US financial support-'become the unwitting hangman of Latin American populism'. ${ }^{14}$

As I have demonstrated, the sharp juxtaposition of social democracy and populism originates in the policing efforts by the neoliberal establishment in Latin America. 'Liberalism, though not always an explicit point of reference, thus lurks near the surface of this debate' and serves as the covert norm. ${ }^{15}$ This is abundantly clear in one recent article, which defines the key challenge facing the region's 'social democratic' left as follows: 'to overhaul the culture and informal institutions of currently existing liberal democracy' since progress will only made 'upon the foundations of strong representative and properly accountable institutions'. It is also possible to detect below the surface an underlying concern about extra-institutional mobilisation and popular majoritarianism, as shown by the author's unease about unruly piqueteros (unemployed workers) being used by radical minorities in Argentina. The article also contains an especially emphatic warning about the 'risks incurred by attempts at instituting a political ground zero in complex modern societies', in other words, anxiety about the 're-foundationalism' characteristic of what is dubbed the non-social democratic left in Latin America. ${ }^{16}$

In practice many social scientists prove almost as uncomfortable with the charismatic, the demagogic and the excessive (emotion not reason) as Michael Reid, an English journalist who has served since 1996 as the Latin American Bureau Chief for neoliberalism's most ideologically rigorous 
publication. While it skipped the Europeanising 'social democratic' label favoured by Castañeda and others, his 2007 book described 'the battle for Latin America's soul' as pitting 'democratic reformism' against 'populist autocracy, as personified by Hugo Chavez'; herein lies 'the populist challenge to liberal democracy ... Strip away the verbiage, and Chávez looks a lot like a typical military caudillo and his project an updating of populism' consisting of a charismatic and messianic saviour directly bonding with the masses through the media, combined with a lack of restraint, unsustainable redistribution and a polity made up of clienteles not citizens. ${ }^{17}$

\section{Reason, passion and the question of populism: the 1990s birth of 'left' neoliberalism}

'A holy alliance is trying to exorcize the ghost of populism', Carlos de la Torre recently noted, but it is possible to 'identify important debates over the meanings and interpretations of democracy ... behind the smokescreen'. ${ }^{18}$ In truth, the question of 'social democracy' has less to do with Latin America than it has to do with Latin American and Latin Americanist intellectuals across lines of ideology and politics. The emergence of this regionally esoteric term, with its current valences, dates to the late 1980's evolution of part of the 1960s generation which cut its teeth on the 'populism' debate that marked the emergence of the Latin American New Left. ${ }^{19}$ Across the subsequent decades a vast amount of research has been conducted on how to best understand the mid-twentieth century populist leaders, movements, governments, culture and regimes. Very little of this, however, has penetrated the world of those who refurbished a revolutionary version of anti-populism as 'social democracy', while effectively-perhaps inadvertently-converting the new Latin American 'social democracy' into 'a recipe for the consolidation of neoliberalism in practice'. ${ }^{20}$

Those who set out to create a 'third way' between the old liberalism and new invading 'neoliberalism', and its national-populist rival were aware that their effort seemed 'unrealistic' and 'incongruous'. ${ }^{21}$ As Cardoso noted, this new 'social democracy' emerged in a region 'besieged by apparently triumphant neoliberalism and weakened by the criticism and death of real socialism', while facing 'a political tradition', populism, that was 'unfavorable to it'. ${ }^{22}$ The term itself was 'not viewed very positively' in Latin America, while the region hardly seemed 'the most ideal breeding ground' for social democracy, especially since it was 'socially and politically ... very close to a situation that conforms to the national populist model'. ${ }^{23}$ Of the voices heard in Vellinga's 1993 programmatic collection entitled Social Democracy in Latin America, the soon-to-be-president Cardoso was clearest in identifying the practical neoliberal tasks ahead: to criticise past lefts, reduce the state, restrict redistribution associated with corporatism (such as wage increases), and move away from nationalist flag waving, usually by leftists. ${ }^{24}$

What needs to come to the fore, Cardoso said, was a concern for efficiency while attending to 'the rational aspects of accumulation, productivity, and investment' so often missed in the regressive critique of wealth associated 
with the 'egalitarian utopia' of Catholic socialism. ${ }^{25}$ Like Cardoso, the Argentine Marcelo Cavarozzi was especially critical of the 'grass-roots left' linked to liberation theology, labour and mass protest. Focusing on the PT as 'the most dramatic example', he criticised a 'Manichean view' that perceived 'political representation, at its best, as a distortion of true and real democracy, which... is associated with modalities of direct participation'. The result was that this grassroots left played an 'ambivalent' role in the transition to democracy while 'increasingly virulent and self-referential assembleyism' provided a playground for militants who used a language 'alien to the popular and working sectors' they claimed to represent. ${ }^{26}$

Despite the fragility of their project, Latin America's self-styled social democrats in the 1990s did aspire to something truly utopian. The goal was not to re-found a nation or grace it with a new constitution, but to erase its history, politics and popular culture as part of putting an end, once and for all, to the 'era of populism' (as Cardoso put it in 1994). The likelihood of success can be measured by the array of past presidents Castañeda identified with populism in his 2006 Foreign Affairs article: it included such twentiethcentury giants as Mexico's Lázaro Cardenas, Argentina's Juan Perón, Brazil's Getúlio Vargas and Bolivia's Victor Paz Estenssoro! The irony, of course, is that you cannot erase or even re-found a country's past, only its future. As I observed in 2006:

the difficulties of transposing a North Atlantic social democratic vision into a Latin American context [are] due to the presence of a sui generis political phenomenon that will come to be known as populism. In terms of practical political realities, the center-left terrain that might have been social democracy was occupied instead by what [US scholar Robert] Alexander (and most foreign observers) could only see as a group of unscrupulous demagogues, opportunistic and often semi-democratic, who were given to anti-American posturing and a tendency to conciliate as well as fight with the anti-imperialist communist left. ${ }^{27}$

The oddity of the utopian aspiration of Castañeda and Cardoso was not completely missed by intellectual architects of the new 'social democracy' of the 1990s. One noted that state action on behalf of redistribution and a lessening of inequality did not differentiate social democratic "policies from the old national populist ones'. ${ }^{28}$ Another recognised that several of the established social democratic parties in Latin America, such as APRA in Peru and AD in Venezuela (members of the Socialist International), were 'tied up' with populism and founded by commanding caudillos like Haya de la Torre and Rómulo Betancourt. ${ }^{29}$ Such fine points, however, are routinely passed over by those who fail to distinguish between social democracy as a flattering self-conceit, an alternative political economy, a set of principles and values, a discourse or a facade. In truth, social democracy in Latin America tracks most clearly with liberal values held dear by the intelligentsia: abstraction and rationality, civility and controlled emotions, distance and irony, and an obsession with North Atlantic modernity in one form or another.

By contrast, populism and the popular, with which it is still often confused, are coded quite differently and therein lies their singular strength. It took an 
English journalist with neoliberal politics to recognise most forthrightly that populism today 'has become a loaded, normative term, rather than an analytical one'. Reid's 2007 book even recognised that populism was often 'a creative political response to inequality and the dominance of powerful conservative groups ... [It served as] the political vehicle through which many Latin American countries entered into the modern era of mass politics' ${ }^{30}$ As Miguel Centeno and Fernando Lopez-Alves have noted, 'the collapse of liberalism in the interwar years generated perhaps the region's first "homegrown" regime model. While clearly influenced by both the Popular Front Left and fascism, Latin American corporatist populism had indigenous ingredients and sought to formulate answers clearly linked to the nature of the [local] economic, political, and social problems they were meant to solve'. 'Whereas liberals and positivists had often looked abroad for inspiration', notes Reid, 'populists promoted national culture' and played 'an analogous role' to European social democracy. ${ }^{32}$

While Touraine considered populism to be in a 'terminal phase of decomposition' in the early 1990s, ${ }^{33}$ Castañeda's 1993 book could not ignore its many positive features and lasting legacies. While decrying populism's timid reformism and frequent resort to authoritarianism, this Mexican leftist en route to a social democratic version of neoliberalism nonetheless emphasised that:

the national-populist tendency undoubtedly belongs on the left of the political spectrum... These movements' original leaders, together with the historical periods of collective consciousness and popular enfranchisement, are symbols of an era and a certain idea of modernity in Latin America: the inclusion of the excluded... Finally, the populist epoch was a golden age of national selfassertion. It was a time when Latin American countries stood up to the rest of the world, gained attention and respect, and defended their pride, dignity, and many of their true interests. ${ }^{34}$

To understand twenty-first century left turns in Latin America demands that we move beyond excessively narrow temporalities while taking into account the historical roots of contemporary politics, both in term of legacies and that which is new. The region's variety of lefts must also be disaggregated into the diverse historical trajectories that affected these plural lefts within the ebb and flow of end-of-the-twentieth century Latin American and global economics and politics. And above all we must attend to the social and the cultural as much, if not more, than the political, institutional and economic. As Torre has noted about populism, politics 'cannot be reduced to the words, actions, and strategies of leaders. The autonomous expectations, cultures, and discourses of followers are equally important in understanding the populist bond. In order to comprehend the appeal of populism serious attention should be paid to the words, communications and conversations between leaders and followers'. ${ }^{35}$ It requires, in other words, that we attend to lived relations between flesh-and-blood individuals and groups, while analysing politics as embodied work done with words by individuals in their relations with others. 
As we do so, Luis Reygadas reminds us, we need to pay special attention to the gaps between our analytical vocabularies and the discursive realm of the subaltern who have emerged as a central force in Latin American polities over the past century. Reygadas notes that intellectuals, and the documents and manifestos they write, often prefer a language of liberal 'citizenship, equality, inclusion and intercultural dialogue'. Yet these weak narratives, he suggests, cannot yet substitute for the 'them-us' logic that structures 'subaltern discourses of inequality [that] go back to a long history of plundering, discrimination, and exclusion'. These images and tropes are not, he insists, 'a simple reflection of that history. On the contrary they are active constructions that interpret the Latin American condition from the perspective and the interests of the excluded. ${ }^{36}$

\section{Two lefts, one path? Chavez, Lula and the politics of Latin America's left turns}

Now we can return to the Caracas WSF speech by a politician far more successful than Castañeda or Cardoso. Those "who have lifted the flags of revolution', Chávez thundered, are on 'a victorious offensive against the Empire' with battles looming in Latin America, Asia and Africa. 'Representative democracy', he went on, 'always ends up being a democracy of the elites and therefore a false democracy'. We want a new model, a revolutionary and 'people's democracy, [one that is] participatory and protagonistic' not one defined by 'an elite that represents the "people". 37 This forceful anti-imperialist, anti-liberal and socialist rhetoric suggests less a revival of Latin American populism, the eternal bête noire of the enlightened, than a rebirth of the Tricontinental Third Worldism of the Cuban Revolution which inspired the 'radical, guerrilla-based Castroist, or communist left' of the $1960 \mathrm{~s}^{38}$ Indeed, Chávez uses the language of struggle, rupture and the seizure of power, whose absence served as the basis of many attempts to define the 'social democracy' of other lefts in the region, especially those of Lula and the PT. Moreover, the genealogy claimed in Chávez's speech raises the uncomfortable question that remains unaddressed by the currently favoured dichotomy: should Chávez perhaps be classified as a 'radical socialist' or a Third World fighter for 'national liberation', perhaps even a Castroite?

Chávez's radical words do in fact stand in stark contrast to the moderation of the rhetoric of his Brazilian counterpart, which would seem to support the notion of a Chávez radical left and a Lula one (however labelled). Before doing so, however, we might consider that, in the very same speech, the Venezuelan president directly criticised leftists who had unfavourably compared the words or actions of Lula to those of his own government. 'Nobody can ask me to do the same as Fidel does, the circumstances are different; like Lula cannot be asked to do the same as Chávez; or Evo cannot be asked to the same as Lula'. He recalled the Porto Alegre WSF the previous year, where he had been more enthusiastically received by a largely Brazilian audience than had Lula. As he observed in Caracas, 'I told my compañeros and brothers of Brazil', at the 2005 WSF Gigantinho, that Lula 'is a great man 
and that they have to work with Lula and support Lula' (who was facing reelection in 2006 as was Chávez-both won with $61 \%$ of the final vote; Chávez on the first round). Above all, he insisted, 'our struggle must be understood as a process' in which presidents and countries have 'their [own] circumstances, but we walk the same path, in the same direction and that's what's important'. ${ }^{39}$

In Caracas Chávez was speaking to an audience favourable to a more resolute and consequential 'leftism' than was characteristic of the Lula government. Despite the moral authority derived from his 'in-your-face' leftist posture, Chávez drew a significantly different boundary between left and right than might be expected given the political genealogy invoked in his speech. Yet do Chavez's efforts to cast the left's net so widely, even promiscuously, make any sense at all? Perhaps they merely reflect his personal friendship with Lula, which goes back to before 1998, or his admiration for Lula's past history of struggle that links both men as insurgents. It might even be an expression of a 'big man' theory of history in which peoples have states and states have rulers, and high-level hemispheric and global politics is the game that powerful men play with each other. This latter possibility seems unlikely, however, since the volatile Chávez has routinely violated diplomatic protocol with harsh comments about the presidents and politicians of other Latin American countries. There is little reason to believe he would hold his tongue if he felt betrayed or disappointed by Lula.

Yet we need not take at face value the Venezuelan president's claim of a single left on the march. Perhaps it is merely opportunistic state craft that led him to minimise his differences with Lula? And is it really possible for Lula to have the 'warm personal friendship with Chávez' of which he boasts, while simultaneously being on excellent terms with the US president denounced by Chávez as the devil? In other words, perhaps the claim that President Lula is of the left stems solely from Chávez's need to curry favour with Lula and his government. A not entirely dissimilar calculus might be said to drive Bush's favourable stance vis-a-vis Lula, which has allowed his government to retain the advantages of apparently incongruous alignments, while refusing to allow either of the parties in conflict to force the country into a definitive position. In this fashion, the Lula government becomes an indispensable point of convergence-between the volatile Chávez and less enthusiastic Latin American governments as well as between Chávez and a US government eager to see him out of power. ${ }^{40}$

That Chávez recognises his own dependence upon Brazilian support leads him to emphasise that Lula is not Cardoso and Lula and his government have not betrayed the left. Although he might prefer a Lula who was more forthright, Chávez is confident that Lula will not harm him or his government; otherwise, he would be first to denounce him. In truth, Lula's Brazil has repeatedly served as a vital guarantor of Venezuela's Chavez in the face of his enemies, just as it has emerged as a support for the government of Evo Morales, despite that government's abrupt nationalisation of the Bolivian properties of the Brazilian state-owned oil enterprise Petrobras. 
And President George Bush, dealt these cards, has no choice but to return over and over again — as recently as 2007 - to a man he describes as a friend and ally. Moreover, Venezuela's twice freely elected president is well aware that Lula attracts support in sectors of global politics that are unenthusiastic about his policies and discourse. In this sense, all three men occupy a place within the space of convergence constructed around Lula, each at various distances to his left and right but all intertwined in the net.

The pro-Lula position assumed by Chávez further clarifies the meaning to be accorded to the idea of the left in Latin America during the twenty-first century conjuncture of neoliberal globalisation. Here we can return to a story that Chávez recounted in his 2006 speech to the Caracas WSF. After hailing Schafik Handel of El Salvador, a legendary communist and one-time presidential candidate of the Frente Farabundo Martí de Liberacion Nacional (FMLN), the Venezuelan president gave an account of the first time he met his fellow revolutionary at the VI Encuentro of the Foro de São Paulo (FSP) held 26-28 July 1996 in San Salvador. The FSP began in a conference of the region's leftist parties and organisations held in São Paulo at the initiative of the PT in July 1990. The FSP Encuentro in San Salvador was the sixth such meeting (São Paulo 1990, Mexico City 1991, Managua 1992, Havana 1993, Montevideo 1995) and Chavez and his compañeros decided to attend.

\begin{abstract}
We went just after being released from jail, and a strange thing happened ... the leftists of Latin America looked on us with trepidation, they kicked us out of the assembly. They had their reasons: 'A colonel who led a military coup. A caudillo.'... There we were, and I remember that I was not allowed to address the Assembly by majority decision by the Forum organizers. I told them: That's fine; I didn't come here to talk to the assembly. I came to see what this is all about, to learn, to learn out about movements, political parties, and leaders, to listen to speeches, to take good notes, to learn to integrate myself. ${ }^{41}$
\end{abstract}

Chávez's story reveals fissures that separated his biographical trajectory from those of the party left, which predominated in the forum, with the leading roles accorded the PT (Brazil), the Cuban Communist Party, the FMLN (El Salvador), PRD (Mexico), the FSLN (Nicaragua), and the Frente Amplio of Uruguay. At the same time it also highlighted the legitimacy that the exprisoner and disgraced military man accorded the FSP as the representative body of Latin America's pluralistic left, and what he believed their recognition might offer to him.

Two years into his presidency, in 2000, the 'singular political process' in Venezuela was hailed in the final declaration of the IX FSP Encuentro in Managua (2000) and Chávez himself would attend the Havana FSP Encuentro of 2001 as a head of state (Lula was also there, having already met Chávez earlier). Yet Chávez's words in Caracas remind us that the ties that bind him to the FSP are not only ideological or strategic but personal. Indeed, this is precisely why Chávez chose to discuss a slight from 1996 that might otherwise have been a source of bitterness. As Chávez recalled with warmth, it was the former communist party guerrilla Schafik who had 'the 
delicacy, the firmness, the courage, the spirit to approach me... and he invited me to the table the he had coordinated, and offered excuses for the debate that resulted from my surprise appearance in the Assembly'. ${ }^{2}$

These personal ties, built up one-on-one and in meetings like the FSP, are a deeper part of what tie the two presidents together. This is illustrated by an earlier Chávez speech to 15000 people who gathered on 30 January 2005 to hear him address the WSF in Porto Alegre. Having cited that speech to his Caracas listeners a year later, the Venezuelan president ended his two-and-ahalf hour Porto Alegre speech with a declaration that, in being so human, was all that much more deeply political. While acknowledging that some in his Brazilian audience might heckle, he declared: 'I love Lula. I appreciate him. Lula is a good man with a great heart. He is a brother and compañero and I leave him my embrace and my appreciation. ${ }^{43}$

\section{Convergence as praxis: neoliberalism, the Forum of São Paulo and the World Social Forum}

While shaped by personal ties and trust, the political foundation that defines the contemporary politics and practice of the Latin American left was laid during a process of convergence over the past twenty years. The Forum of São Paulo was founded in a darkly pessimistic period for the left and its key role was to serve as a space of convergence marked by a pluralism of traditions, ideologies, forms of struggle and styles of leadership. In its convocation and conduct, the FSP reflected a characteristic style of leftist organising that characterised Lula, the PT, the Brazilian left and its allied social movements. Addressing the 15th anniversary Encuentro in 2005, President Lula recalled 1990, 'when we were few, discredited, and we talked a lot. The Forum of São Paulo, in truth, taught us to act like companheiros, even in our diversity'. After all, those involved 'did not think in the same manner (jeito), didn't believe in the same prophecies, but did believe that the Foro de São Paulo could be a path ... In the beginning ... some parties didn't wish to participate, because they thought we were a bunch of crazies [malucos]... Meetings were not easy, [but] difficult; many times the divergences were greater than the agreement but there was always a group that played mid field to contemporarize, to seek the right word. ${ }^{44}$

Across its Encuentros, the central opponent was invariably defined as neoliberalism and, to a somewhat smaller degree, US imperialism. In the 2007 words of another founder, the FSP encompassed 'the entire ideological spectrum of the left. With an anti-imperialist and anti-neoliberal definition, the FSP represents a space where the different member organizations can meet each other, a space for debate, and a mechanism for communication, coordinating, and solidarity. ${ }^{45}$ The founding of the FSP came a year after Lula's first presidential campaign in 1989, which he lost by only six percent of the national vote. At the time Brazil had seen the rise of mass anti-systemic social movements, a radical and militant grassroots oriented 'New Unionism,' and a party whose radicalism placed itself outside the boundaries of even a re-founded Brazilian democracy (the refusal to vote for Tancredo 
Neves in indirect elections in 1985; the refusal to sign the democratic constitution of 1988). In many ways, the PT represented the ideal case to address the relationship between popular insurgencies, social movements and a radical leftist political party pledged to socialism. Based on a 'logic of difference' in the words of Mimi Keck, the PT was a movement-uneasilyturned-party that exemplified the tension between rejection and participation that bothered Cavarozzi, while its party documents took a militantly leftist stance, except for its rejection of the Soviet model (though sympathetic to Cuba and Sandinista Nicaragua). ${ }^{46}$

As the first election after a 21 year military dictatorship, the 1989 campaign was a tense and polarising one. It was in this charged context, at the most radical moment in the PT's history, that Lula was asked in a radio interview how he intended to save Brazil from 'savage capitalism' and take it towards socialism. He replied:

I never liked the nomenclature 'savage capitalism'. I always thought such savage capitalism doesn't exist, I know of a capitalism that bites and that doesn't bite, that which is bad and that which is good. I think that there has been a retrograde mentality on the part of Brazilian businessmen, the government, and the dominant class. As I've said, when it comes to earning money, Brazilian businessmen are as modern as the Europeans but, when it comes to paying wages, they are backwards like the English of a century ago. So what I think is that we need a new dynamic, not just economic but cultural, so that those people begin to understand that it is essential to distribute income.

Having used his words to deflect impressions of radicalism, Lula went on to offer an accurate preview of the objectives of his future presidential administration-13 years before its inauguration: 'I would say that we are elaborating a program of government that will prioritize some things in the social camp. I would not say that we're going to make socialism. ${ }^{47}$

The point is not that Lula was a social democrat before his time or to repeat earlier criticism of the scholarly utilisation of stylised European categories that obscure the actual complexity of any given left. Today's attempts to 'baptise' Lula and the PT in their faith reflect a failure to understand the specificities of the Brazilian as well as Latin American contexts. As French and Fortes observed in 2005, 'the PT was a pluralistic party that included Marxist-Leninist revolutionaries, practitioners of liberation theology and New Deal-style social reformers', even social democrats and liberals. It eschewed ideological definitions, idealised a bottom-up participatory politics and was constructed as 'a point of convergence characterized by an absence of doctrinal rigidity and a high social density'. ${ }^{48}$

The PT was founded on an event, a personality and an image and was characterised, by one Marxist petista (PT militant) in 1987, as a 'heterogeneous organization' with a 'hybrid outlook' based on a 'remarkable - and probably unstable - ideological identity'. What 'distinguished the PT from the outset was a unique compound of two outlooks that would normally be regarded as incompatible': a 'potentially sectarian workerism' and what Eder Sader called 'an uncritically received liberalism'. ${ }^{49}$ The ability to maintain 
this heterodox confluence of forces, tendencies and ideologies depended upon the forging of bonds of group-belonging, the crafting of a shared story, and a partistan petista identity, if not project. Lines needed to be drawn, but the PT's strengths lay in its leader (a fact usually ignored out of leftist orthodoxy), and the open-ended terrain of the PT functioned best as a space of convergence that tolerated difference and even internal factions. The presiding inspiration was well put in Lula's remarks to the VI Encuentro of the FSP in 1996: 'We must place much less importance on our ideological differences and much greater emphasis on united action. We must abandon the sectarian spirit that so often has dominated and divided us. That means ending the traditional arrogance that has characterized the left. ${ }^{, 50}$

In the 1990s the PT stood with those sectors of Latin American politics that consistently criticised the neoliberal policies of the centre-right government led by Cardoso. Yet what was gained in strategic political terms by the left's deployment and popularisation of the term neoliberalism? If opposition to neoliberalism, not to capitalism, marks the fundamental boundary of the contemporary left, as I would argue, the terminology could be said to obscure the essential capitalist and imperialist enemy, if viewed in orthodox Marxist terms. Yet the emphasis on neoliberalism is especially appropriate to Latin America, where autonomous or semi-autonomous national development (be it capitalist or socialist) has long been a shared goal across the political spectrum. While anti-capitalism has had its place in the discourse of the region's left, the practical emphasis has more often been on the incapacity of capitalism to achieve the autonomous national development being sought, while the bourgeoisie has long been criticised for failing to spark a bourgeois democratic revolution or deliver prosperity to the masses.

As first popularised in Latin America, neoliberalism brilliantly delineated a vague and shifting opposing camp that correctly frustrates those who favour the political forces associated with the Washington Consensus of 1989. The Economist bureau chief in São Paulo in the late 1990s, for example, was especially irritated by the slipperiness of the term. In his 2007 book, Reid recognises that the Washington Consensus is now 'indeed an irrevocably damaged brand'. Yet a frustrated Reid rightly notes that its 'central tenetsof macroeconomic stability and open, market economies-have [now] become an enduring part of the scenery in many countries in the region. That this is not more widely perceived', or convertible into political capital, 'owes much to the baleful influence of a meaningless term: "neoliberalism".' While recognising neoliberalism's ties to the discredited Pinochet and Menem, Reid seeks to rescue its policies from the obloquy to which neoliberalism is currently subjected: "neoliberalism" is widely used by its critics either simply to describe an open capitalist economy, or as a term of abuse'. While citing the Chilean Concertación as the best example, Reid then dubs Lula a 'social democrat' and 'a convert to this consensus' although, he adds, 'in some way an ambivalent one'. ${ }^{51}$ In offering the same caveat as Castañeda, Reid thus confirms that the neoliberal camp is aware that Lula's leftism falls short of being fully assimilable. 
With the passage of time, the PT and the Brazilian left creatively developed the language and practice of anti-neoliberalism so that they were prepared, by the dawn of the new millennium, to take it to the global level. The WSF Charter was the product of dialogue between Brazilian social movements, mostly but not entirely hegemonised by the PT, and the ATTAC group in France in the late 1990s. In its basic principles, the Charter defines a very broad space of convergence that disregards past ideological disputes or current rivalries within the left. The goal is a space in which a vast array of forces, projects and currents can come together around a lowest common minimum. Indeed, the first point of the 2001 Charter of the non-party WSF was to bring together 'groups and movements of civil society that are opposed to neoliberalism and to domination of the world by capital and any form of imperialism, and [who] are committed to building a planetary society directed towards fruitful relationships among humankind and between it and the earth'. 52

The WSF is not defined-nor is the contemporary Latin American leftnecessarily by opposition to capitalism per se but to neoliberalism. It is not defined by opposition to all capital but to 'domination ... by capital', and, while unequivocally opposed to 'any form of imperialism', it does not assert that all capitalist countries are necessarily imperialist. As a result, the WSF process would come to encompass, over subsequent years, countless celebrities, French cabinet ministers, Nobel Prize-winning economist Joseph Stiglitz, formerly of the World Bank, and the international financial speculator George Soros. In ideological terms it attracted anarchists, socialists, communists, social democrats and liberals, not to mention the unaffiliated and a vast array of labour, environmental, women's and indigenous groups. Under such circumstances, those obsessed with defining the left in terms of 'Revolution' or 'social democracy' are caught up in a midtwentieth century past whose relevance is fading in the face of today's challenges. $^{53}$

\section{Comparing the men and the words: Chávez's and Lula's distinctive styles of leadership}

Chávez's refusal to label Lula a neoliberal does not mean that the Venezuelan president likes Lula's policies. Nor does it indicate his acceptance of the model of politics implied by the new global thinking on the left represented by the WSF. In hosting the WSF, Chávez clearly accords status and legitimacy to this Brazilian-identified global convergence, but his speech also illustrates the difference between his politics and those of Lula, of the PT and of the largest current within the World Social Forum. The Venezuelan president not only positions himself to the militant Marxist left of the WSF but explicitly criticises the WSF's self-definition as a process not an organisation: as 'an open meeting place for reflective thinking, democratic debate of ideas, formulation of proposals, [and the] free exchange of experiences'. ${ }^{54}$ Rather than constituting the WSF as a new leftist international, the forum aspires to serve as a pluralistic space of encounter by civil society, a movement of 
movements, with an emphasis on horizontality and autonomy (its particular strengths).

While affirming his government's respect - in 'an almost sacred way' - for 'the autonomy of the social movements' represented in Caracas, the Venezuelan president showed little patience for rules that preclude formal WSF manifestos and plans of action. While making abundant use of military metaphors (offensives, victories, battles, retreats), Chávez insisted on the need for 'the perfect strategy for the coming years... We have to link up all our causes, [we need] unity, unity, unity'. The WSF, he warned, runs the risk of becoming simply a 'folkloric tourist encounter' unless it can 'agree to a united work plan, a united universal plan of action' for the upcoming battles so 'vital for the future of the world'. Otherwise, 'we would just be wasting our time'. While mentioning respect for diversity and autonomy once, the word 'unity' appears a dozen times in this section of Chávez's remarks. After using it, he immediately offers a revealing 'clarification': 'no one is planning to impose anything on anyone, only coordination, unity' [ie an imposition]. A brief reference to vital pending battles then ends abruptly with 'Look, Karl Marx coined the phrase: "Socialism or death", 55

Chavez is clearly critical of what he takes to be the WSF's diffuseness and excessively cautious politics; indeed, he is more openly critical of the WSF than of Lula himself. And these remarks demonstrate why his presence at the WSF sparked controversy, as did Lula's second appearance in 2005, though for different reasons. Although welcome in a personal capacity under the charter, both men are elected heads of state as well as charismatic leaders whose rise is based upon a relationship - constituted through identification, emotion and imagination - with a mass base of tens of millions. Both are men of passion as well as reason, with anger being most starkly identifiable in Chávez, while Lula is known for his smiles, humour and moments of empathy that call forth his tears. While their discursive repertoire and use of metaphor and symbolism differ to a degree, the greatest difference is to be found in how they position themselves in relationship to their listeners. While Lula touches a 'deeply messianic nerve of Brazilian popular imagination', the former metalworker does so as one of the subaltern who had 'succeeded through his experience of the common' and whose individual success is presented as 'expressly collective'. 56

As a former military man from a lower middle class family of teachers, Chávez, by contrast, rose to middling success within a core institution of the state as an officer not a subaltern. Unlike Lula, his persona was not constructed through a sequence of combative mass struggles in dialogue with 150 000 followers. Rather, his political activism originated in a clandestine politics of small groups and his rise from obscurity came as a revolutionary conspirator and a failed leader of a 1992 military coup d'état against an elected government. The process of identification and the forging of imagined relations with Chávez began with his famous three words on TV after his first coup attempt in 1992. ${ }^{57}$ After a second failure, Chávez discovered his true talent: as a politician, with a way with words, who would rise to power through electoral means. Not surprisingly Chavez has a very different relationship to 
the national imaginary, and the structure of feeling surrounding his success is quite different from Lula's case, where 'one of us' has succeeded.

While Chávez initially aspired to a military seizure of power, the twists of history led him to revolutionise his country through successive elections in a tumultuous sequence of struggles, near defeats and triumphs as president. Yet the 'most potent weapon' of Chávez, according to Venezuelan literary critic Yolanda Salas in a 2004 interview, was 'his use of language. He is someone who is skilled at wielding discourse and fascinating the [deprived and excluded] masses ... I call him the great storyteller of Venezuelan politics. He's always got a great narrative, a great story, something great to say, something that seduces... And if anyone knows the popular imaginary, it's Chávez', who has stolen it [sic] 'from us, because he uses it, he controls it, he manipulates it'. ${ }^{3}$

In her anguish Professor Salas speaks for others like herself and shows a critical self-awareness of the illusions that had too long characterised the intelligentsia. Chavismo laid bare the exclusions that underlay the 'myth of democracy' and Venezuelans' fantasies that they lived in a country that had had attained 'an advanced stage of development, that we were cosmopolitans'. Chávismo revealed another Venezuela whose collective consciousness was characterised by 'certain profound traditional images. Just when we thought we were no longer a rural country, Chávez comes along and capitalizes on a popular symbology which is rural in origin'. Those on the top, Salas concluded, had missed those Venezuelans and hadn't seen them 'as real human beings, hadn't recognized them'; even the intellectual's treasured discourse about 'civil society' didn't reach them. ${ }^{59}$

The emerging Chavista discourse called for an end to the 'pillaging, appropriation and extermination' of the 'pueblo-pobreza', which originated with the conquest but continues to this day under a squalid corrupt oligarchy backed by foreign exploiters. ${ }^{60}$ The dialogue between Chávez and subaltern representations of inequality analysed by Reygadas are striking. These representations, he observes, 'synthesize complex social processes into simple dramatic images with emotional and ethical elements' by resorting 'to the archives of historical memory to recuperate easily identifiable images: the abuse of colonial powers, the mistreatment of indigenous populations, black slavery. On this basis they [subalterns] interpret contemporary grievances' through anachronistic images 'of another era with little correspondence to the present... These temporal imbalances have symbolic and political efficacy: they settle accounts with the ghosts of the past and ... should not be interpreted as [signs of] immobility or immutability' but rather as products of 'a continuous reconstruction that reclaims many elements of previous configurations, but is also open to contingency and change'. ${ }^{61}$

In this world of subaltern representations, Reygadas emphasises, 'the intentional aspects of inequality are generally underscored', whether through actions or inactions, and all guilt is attributed to the powerful. Material, moral and psychological suffering is not represented as the result of the disembodied processes and abstractions favoured by intellectuals of all political outlooks (market failures, globalisation, capitalism). And the 
government and its leaders are considered the most responsible for poverty and suffering, with the expectation that they will 'be the chief component in its resolution', 62 and will do so in a direct, immediate and visible way. It is here that we arrive at the grandiose and direct identification between leader and nation, between leader and pueblo-pobreza, between comandante and follower in Chavismo. ${ }^{63}$ But for this to occur requires concrete results not mere words (whose power is often overestimated).

In a sense the role of pedagogue that thrilled Chavéz early in his military career has been scaled up as president, but he is still on centre stage talking down to often adoring audiences. In a July 1977 letter to his parents, the young Chávez described giving a patriotic lecture to an audience of 500 high school students in the name of the nation.

When I was standing on the stage before beginning, the school choir sang the National Anthem. I felt a great emotion, I felt the blood surge through my veins, and my spirit burned so much, and I gave one of the my best presentations... At the end, the students couldn't stop applauding... [and] it seemed to me that I was carried away to a future time... [and] that it might be that I would achieve what I desired and become happy. ${ }^{64}$

Two years earlier, Lula had been elected president of the metalworkers union as an apparent patsy for its former president. Having rarely spoken publicly in his early years in union leadership, Lula nervously fingered something written for him but, pre-empted by the former president, ended up not saying a word. For Lula, as with the poor and subaltern, there first had to be a fight to gain voice in a society characterised by subalternising hierarchies and despotic rule both politically and in the factory. Putting aside the individual Lula, it is vital to better understand how the world looked to these workers at mid-century. To use Brazilian parlance, the common people (povo) had few illusions about the power realities they faced, although they had an acute awareness of their own miséria (misery), combined with a deeply engrained sense of being unjustly treated (injustiçado) at the hands of the more powerful. The result was that manifest discontent coexisted with high levels of dissimulation within a mass consciousness permeated by a sense that the world was stacked against the poor, the weak, the coloured and the uneducated.

Another defining feature of the consciousness of these working folk was their perception of themselves as small and weak; hence the cultivation of guile and cunning as their weapon of choice vis-à-vis the powerful. Malicia or astúcia (cunning) was also admired in those who wished to be leaders, as with Lula, who proved a master of being everything to everyone. To make these possibilities real required a leader capable of manoeuvring within existing power relations to take advantage of small rifts among the superordinate, without being reduced to them. Since defiance of superiors was immediately punishable, to be a leader required the ability to relate to and manipulate those antagonistic to your interests and desires - all the more so if committed to a transformative or struggle-oriented practice. At the same time, the price of such manoeuvre was the suspicion of the led, so it was essential that they believe in your integrity, commitment and loyalty. Here, I return to my 
proposed formula that leadership is a relationship and politics is an embodied work that is done with words; hence the fundamental importance for mobilisation of a leader, in this case one of your own, who you come to judge as reliably worthy of your faith as part of a pact of reciprocity.

The central thrust of my overarching argument about the nature of politics is that leadership, understood as process and relationship (two-way even if asymmetrical), is the causal link between mass consciousness and mobilisation. As in all mass political phenomena, Lula's practice of leadership shares much with that of Hugo Chávez. The key differences between the two are 1) Lula's strategy of drawing people into a space for convergence across difference, which I have argued is a key contribution to a twenty-first-century left; 2) Lula's central focus on organising the popular sectors on a more enduring and autonomous basis; and 3) Chávez's preference, in attracting diversity into a following around him, to act as their 'representative', their epitome, their condensation - while conducting a relation between leader and led on a more top-down basis, characterised by individualism and a resort to 'unity' (command) not convergence (persuasion).

\section{Conclusion}

My forthcoming book Lula's Politics of Cunning: From Trade Unionism to the Presidency will explore how the mass movements of the 1970s came into being in symbiosis with Lula, who became a larger-than-life personality whose trajectory both epitomised and transformed the movement's participants. Brazil's Lula, in other words, was born by accompanying the workers of the industrial ABC region of Greater São Paulo workers through a particular sequence of events, drawing strength from the workers, and helping to forge a new collective identity that took the 'leader' and the 'led' to places that they had never dreamed of or anticipated. Coming out of this localised process, the same skills and talents-backed up by the symbolic capital and moral authority of those events - was then applied by Lula to building more ambitious and coherent instruments for carrying out popular struggle (Lula is very much a disciplined organisation man, unlike Chávez). Over the same period Lula has honed his ability to speak directly and from the heart to tens of millions of voters and, with time, to win over tens of millions of others, as his appeal broadened to include both those above and below him on his path to the presidency.

Keeping an eye on society as much if not more than on the polity, my interpretive biography of Lula will argue for a counter-definition of politics as embodied work that is done, with words, by individuals in their relation with others. In valorising the social, cultural and discursive, such an anthropological approach is used to capture the subaltern origin of Lula's distinctive style of political leadership from trade unionism to the presidency. Across the past three decades Lula has practiced a transformative politics of cunning characterised by an additive politics, executed through the creation of spaces of convergence across difference, and carried out through an embodied work that is done with words. Most importantly, this notion of 
convergence has much to contribute to the politics of a twenty-first century left that seeks to build a post-neoliberal world: the creation of spaces of convergence across difference in pursuit of common values and an unknown, post-neoliberal, not post-liberal, future.

\section{Notes}

1 H Chavez, 'Act for the people's anti-imperialist struggle, VI World Social Forum, Poliedro, Caracas, Friday January 27, 2006', at http://www.chavezinenglish.org/2006/WSF2006.html, accessed 15 March 2008; and Chavez, 'Rise up against the Empire: address to the United Nations', Counterpunch, 20 September 2006, at http://www.counterpunch.org/, accessed 15 March 2008.

2 J Castañeda, Utopia Unarmed: The Latin American Left after the Cold War, New York: Alfred Knopf, 1993. See also my appreciation of the book: JD French, 'The Latin American labour studies boom', International Review of Social History, 45 (2), 2000, p 289.

3 J Castañeda, 'Latin America's left turn', Foreign Affairs, May/June 2006.

$4 \mathrm{Ibid}$. For Castañeda on populism, see Utopia Unarmed, pp 39-40, 43-45.

5 Castañeda, 'Latin America's left turn'.

6 Ibid.

7 Ibid.

8 Castañeda, 'Latin America's Left Turn', emphasis added.

9 For a fascinating personal account of the relationship between Fidel Castro and Lula since their first meeting in 1980, see the recollections in four parts by Fidel Castro, 'Lula', La Jornada, 25 and 30 January 2008, 6 February 2008.

10 Castañeda, 'Latin America's left turn', emphasis added.

11 Those writing about Latin America routinely use 'social democratic' as if it were a known and unchanging category, when this very issue has been the subject of immense debate within western Europe since the 1980s. See D Sassoon, One Hundred Years of Socialism: The West European Left in the Twentieth Century, New York: New Press, 1996; G Moschonas, In the Name of Social Democracy: The Great Transformation, 1945 to the Present, London: Verso, 2002; and G Eley, Forging Democracy: The History of the Left in Europe, 1850-2000, Oxford: Oxford University Press, 2002.

12 K Roberts, 'Repoliticizing Latin America: the revival of populist and leftist alternatives', Woodrow Wilson Center Update on the Americas, Washington, DC: Woodrow Wilson Center, 2007, p 5.

13 E Zedillo, 'Lula: the end of Latin American populism?', Forbes, 170 (13), 2002, p 55.

14 Zedillo, 'Lula'.

15 J Beasley-Murray, M Cameron \& E Hershberg, 'Left turns: an introduction', in this issue.

16 F Panizza, 'The social democratization of the Latin American left', Revista Europea de Estudios Latinoamericanos y del Caribe, 79, 2005, pp 100-101, emphasis added; and Beasley-Murray et al, 'Left turns'.

17 M Reid, Forgotten Continent: The Battle for Latin America's Soul, New Haven, CT: Yale University Press, 2007, pp xiv, 13, 12, 79-80.

18 CT Torre, 'The resurgence of radical populism in Latin America', Constellations, 14 (3), 2007, p 385.

19 M Mackinnon \& Mario Petrone, Populismo y Neopopulismo en America Latina: El Problema de La Cenicienta, Buenos Aires: Editorial Universitaria de Buenos Aires, 1998.

20 P Cammack, 'Cardoso's political project in Brazil: the limits of social democracy', Socialist Register 1997, London: Merlin Press, 1997, p 241.

$21 \mathrm{M}$ Vellinga, 'The internationalization of politics and local response: social democracy in Latin America', in M Vellinga (ed), Social Democracy in Latin America: Prospects for Change, Boulder, CO: Westview Press, 1993, p 3; and A Touraine, 'Latin America: from populism toward social democracy', in Vellinga, Social Democracy in Latin America, p 297.

22 FH Cardoso, 'The challenges of social democracy in Latin America', in Vellinga, Social Democracy in Latin America, pp 274-275.

23 M Vellinga, 'The internationalization of politics and local response', pp 4, 12; and Touraine, 'Latin America', p 304.

24 Cardoso, 'The challenges of social democracy in Latin America', pp 284-286, 289.

25 Ibid, pp 284-285.

26 M Cavarozzi, 'The left in South America: politics as the only option', in Vellinga, Social Democracy in Latin America, pp 154-5.

27 JD French, 'The labouring and middle-class peoples of Latin America and the Caribbean: historical trajectories and new research directions', in Jan Lucassen (ed), Global Labour History: A State of the Art, Bern: Peter Lang, 2006, pp 304, 306. 
28 Touraine, 'Latin America', p 303.

29 Vellinga, 'The internationalization of politics and local response', p 13.

30 Reid, Forgotten Continent, p 12.

31 M Centeno \& F Lopez-Alves, The Other Mirror: Grand Theory through the Lens of Latin America, Princeton, NJ: Princeton University Press, 2001, pp 5-6.

32 Reid, Forgotten Continent, pp 79-80.

33 Touraine, 'Latin America', p 304.

34 Castañeda, Utopia Unarmed, pp 43, 39-40, 44, 42.

35 Torre, 'The resurgence of radical populism in Latin America', p 392.

36 L Reygadas, 'Imagined inequalities: representations of discrimination and exclusion in Latin America', Social Identities, 11 (5), 2005, p 504.

37 Chávez, 'Act for the people's anti-imperialist struggle'.

38 Castañeda, 'Latin America's left turn'.

39 Chávez, 'Act for the people's anti-imperialist struggle', emphasis added.

40 See Lula's adept handling of this challenge in a 24 February 2006 interview: LI da Silva, 'The working man's statesman gives a rare interview to the Economist', The Economist, 5 March 2006, pp 2-3.

41 Chávez, 'Act for the people's anti-imperialist struggle'.

42 Ibid.

43 H Chávez, 'Foro Social Mundial: el sur, norte de nuestros pueblos desde el gimnasio gigantinho. Porto Alegre Brasil 30 de Enero de 2005', at http://www.mre.gov.ve/Noticias/Presidente-Chavez/A2005/ Discurso-030.htm, accessed 15 March 2008.

44 LI Silva, Discurso do Presidente da República, Luiz Inácio Lula da Silva, no Ato Político de Celebração aos 15 Anos Do Foro de São Paulo, Brasília: Presidência da República Secretaría de Imprensa e Divulgação, 2005, pp 2, 4-5.

45 R Regalado, Latin America at the Crossroads: Domination, Crisis, Popular Movements and Political Alternatives, Melbourne: Ocean Press, 2007, p 249. The author is a member of the Cuban Communist Party Central Committee.

46 M Keck, The Workers Party and Democratization in Brazil, New Haven, CT: Yale University Press, 1992; and Cavarozzi, 'The left in South America'.

47 J Nêumanne, Atrás do Palanque: Bastidores da Eleição 1989, São Paulo: Siciliano, 1989.

48 JD French \& A Fortes, 'Another world is possible: the rise of the Brazilian Workers' Party and the prospects for Lula's government', Labour: Studies in Working Class History of the Americas, 2 (3), 2005, pp 14, 18.

49 E Sader, 'The Workers Party in Brazil', New Left Review, 126, 1987, pp 100, 97-98.

50 'XIII Foro de São Paulo: something to celebrate in El Salvador', NotiCen: Central American and Caribbean Affairs, 8, February 2007.

51 Reid, Forgotten Continent, pp 10-22.

52 WSF, 'Revised World Social Forum Charter of Principles, June 2001 Version', in Jai Sen et al (eds), World Social Forum: Challenging Empires, New Delhi: Viveka Foundation, 2004, p 70, emphasis added.

53 For a contemporary Cuban communist perspective that emphasises revolution and armed struggle, see R Regalado, Latin America at the Crossroads, pp 222, 232.

54 WSF, 'Revised World Social Forum Charter of Principles', p 70.

55 Chávez, 'Act for the people's anti-imperialist struggle', emphasis added.

$56 \mathrm{~J}$ Holston, Insurgent Citizenship: Disjunctions of Democracy and Modernity in Brazil, Princeton: Princeton University Press, 2008, pp 5-6.

57 See Naim's account of the impact of 'unfortunately, for now' in K Hawkins, 'Populism in Venezuela: the rise of Chavismo', Third World Quarterly, 24 (6), 2003, p 1148.

58 R Rivas Rojas \& Y Salas, 'On Chavismo: interview with Yolanda Salas (Caracas, 7 September 2004)', Journal of Latin American Cultural Studies, 14 (3), 2004, p 328.

59 Ibid, pp 328-329.

60 Hawkins, 'Populism in Venezuela', p 1147.

61 L Reygadas, 'Imagined inequalities', pp 502-504.

62 Ibid.

63 Hawkins, 'Populism in Venezuela', p 1154.

64 A Zago, La Rebelión de Los Ángeles, Caracas: Fuentes Editores, 1992, p 25, cited and translated in Hawkins, 'Populism in Venezuela', p 1147.

\section{Notes on Contributor}

John D French is a Professor of History at Duke University whose specialties include labour and politics in Brazil and the rise of alt-global politics. His 
books include The Brazilian Workers' ABC: Class Conflict and Alliances in Modern São Paulo (1992) and Drowning in Laws: Labor Law and Brazilian Political Culture (2004), as well as a 1997 co-edited volume The Gendered Worlds of Latin American Women Workers. He is currently finishing a manuscript entitled Lula's Politics of Cunning: From Trade Unionism to the Presidency in Brazil. 